(C) 2000 The Chemical Society of Japan

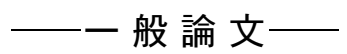

\title{
主鎖に二置換アミド型ノルボルナジエン構造を有する ポリ(エステル/アミド)の物性とその耐候性
}

\author{
(2000 年 4 月 3 日受理)
}

長部友加里 ·亀山 敦 $\cdot$ 中村茂夫 ·西久保忠臣*

\begin{abstract}
主鎖に二置換アミド型ノルボルナジエン $(\mathrm{NBD})$ 構造を有するポリ（エステル/アミド) $(\mathrm{P}-1)$ の耐候性 とその向上について検討を行った. P-1のフィルム状態での屋外暴露試験を行った結果, 暴露期間の経 過とともに蓄熱量が減少し, 架橋反応や主鎖の切断が起ることが判明した. 一方, P-1 フィルム表面を ポリビニルアルコール $(\mathrm{PVA})$ フィルムで保護した試料について同様に屋外暴露試験を行った結果, PVA で保護することにより蓄熱量の減少が抑制され，P-1 フィルムの耐候性を向上させることが可能 であることが明らかとなった。 また, P-1に光安定剤を添加し, 同様に耐候性の検討を行った結果, 暴 露 90 日までは, 蓄熱量の減少は見られず, P-1フィルムの光-熱変換機能が安定に作用することがわ かった．さらに，P-1 をガラス板で保護した場合にも耐候性の向上が認められた．以上のことから， NBD ポリマーの表面を保護すること, および光安定剤を添加することにより, NBD ポリマーの耐候性 が効果的に向上することが判明した。
\end{abstract}

\section{1 緒訔}

近年，化石エネルギーの枯渴が深刻な問題として取り上げら れ, 太陽エネルギー有効利用の観点から光-熱変換・蓄積システ ムの開発が提案されている1). 光エネルギーを化学エネルギー (ひずみエネルギー)に変換する有機化合物が幾つか知られている が, 光異性化の量子収率, 蓄熱するひずみエネルギー, 光異性化 および逆異性化の可逆性を考慮した場合, 最も有用な光-熱変換 システムは，ノルボルナジエン $(\mathrm{NBD})$-クワドリシクラン $(\mathrm{QC})$ の光原子価異性化システム ${ }^{2)}$ である. NBD は, 紫外光の照射に より対応する $\mathrm{QC} へ$ と光原子価異性化し, 光エネルギーをひずみ エネルギーとして蓄積する.さらに, $\mathrm{QC}$ は, 適当な触媒との接 触や短波長の光の照射により $\mathrm{NBD}$ 々逆異性化し，その際に蓄 積したひずみエネルギーを熱エネルギーとして放出する3). また， NBD 構造を有する高分子は, その光-熱変換機能に加えて, 高 分子の特徵である軽量性, 成形性, 形態安定性などの優れた性質 を有することから，新しい光機能材料としてさまざまな形態での 利用が考えられている.

このような観点から西久保らは，NBD 構造を有するさまざま な光-熱変換 ·蓄積高分子の合成とその光反応について検討を行 ってきた4)-7)。例えば，2,5-NBD-2,3-ジカルボン酸 (NDC) と種 々のビスエポキシ化合物との重付加反応によるポリエステルの合 成や4), NDC とジイソシアナート類との重付加反応によるポリ

神奈川大学工学部応用化学科, 221-8686 横浜市神奈川 区六角橋 3-27-1
アミドの合成5)など，主鎖に NBD 構造を有するポリマーの合 成，また側鎖に反応性基を有するポリマーと種々の NBD 誘導体 との高分子反応による側鎖に NBD 構造を有するポリマーの合成 が報告されている ${ }^{6)}$. 最近，西久保らは，主鎖に NBD 構造を有 するポリマーの光反応性抢よび耐久性の向上を目的として，主鎖 に二置換アミド型 NBD 構造を有するポリ(エステル/アミド)の 合成と光反応について検討を行っている7). 得られたポリマー は，増感剂を添加することにより，光反応は著しく向上し，94 $\mathrm{kJ} / \mathrm{mol}$ 程度の蓄熱量を有することが報告されている．このポリ マーは，主鎖骨格中にアミド結合やビスフェノール A のような 硬い構造を有することから機械的性質に優れ，幅広い分野での利 用が期待できる.

今後, このポリマーを太陽光エネルギー変換 ·蓄積高分子とし て有効に利用するためには，その耐候性を明らかにすることが重 要であり，さらにその耐候性を向上させる工夫が必要である。一 般に，紫外線を吸収する発色団を有する高分子において，屋外暴 露をすると, 太陽光によりラジカルが生成し, 自己酸化反応が進 行することが知られている8 合して, ペルオキシドラジカルとなり，引き続いて連鎖反応を引 き起こす9)10)．最近著者らは，この自己酸化反応を抑制すること を目的として，NBD ポリマーのフィルム表面をPVA でコーテ イングし, 空気中の酸素を遮断することで, 屋外暴露における副 反応を抑制し，耐候性の向上が可能であることを見いだし た11). なた, NBD ポリマーに光安定剤を添加し, 発生したラジ カルや活性酸素ラジカルを捕捉することにより，NBD ポリマー の耐候性が向上するものと考えられる. 
このような観点から本研究では, 主鎖に二置換アミド型 NBD 構造を有するポリ (エステル/アミド) (P-1)のフィルム状態での 耐候性を明らかにすることを目的とした．また，耐候性の向上を 目的として，P-1フィルムの表面を PVA フィルムやガラス板で 保護した場合の NBD ポリマーフィルムの耐候性について検討を 行った. さらに, 光安定剤を添加効果についても検討を行ったの で報告する。

\section{2 実験}

\section{1 試薬および溶媒}

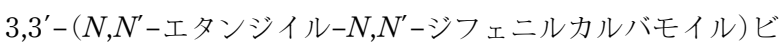
ス(ノルボルナジエン-2-カルボン酸) (EDPNC)は, 既報7)に従い 合成した. ビスフェノール A ジグリシジルエーテル (BPGE) は 市販のエポキシ樹脂 (エピコート 828)をメタノールとエチルメチ ルケトンの混合溶媒 $(v / v=4 / 1)$ で 4 回再結晶したものを使用し た．テトラブチルアンモニウムブロミド (TBAB) は市販品を乾燥 酢酸エチルで再結晶して使用した。N-メチル-2-ピロリドン (NMP) は乾燥剤として水素化カルシウムを用い, 蒸留精製した ものを使用した. テトラヒドロフラン (THF), 酢酸エチル, メ タノールは乾燥剤としてナトリウムを用い, 蒸留精製したものを 使用した。ポリビニルアルコール (PVA)（完全けん化型, 重合 度 : 2000 , 和光純薬工業侏製) は, 市販品をそのまま使用した。 Cyasorb UV 1084および Cyasorb UV 3346 (Cytec industries inc. 製)は，市販品をそのまま使用した。

\section{2 測定装置}

赤外吸収スペクトルは日本分光侏製 FTIR-420を用いて測定し た. ${ }^{1} \mathrm{H}-\mathrm{NMR}$ は日本電子侏製 JNMFX 200 を用いて測定した. 融点はヤマト科学侏製 MP-1を用いて測定した。ゲル浸透クロマ トグラフィー(GPC)には，東ソー侏製 HLC 8020 装置に TSK gel G1000H を装着し，溶離液に THF を用い， $1.0 \mathrm{~mL} / \mathrm{min}$ の流 速で $40{ }^{\circ} \mathrm{C} に て$ 行い, 標準物質として標準ポリスチレンを使用し た. 示差走査熱量計 (DSC), 熱てんびん示差走査熱分析 (TG/ DTA) はセイコーインスッルメンツ侏製 EXSTAR 6000 (DSC 100 抢よびTG/DTA 220 ) (測定条件 : 窒素気流下, 昇温速度 10 ${ }^{\circ} \mathrm{C} / \mathrm{min}$ )を用いて行った. 熱応力ひずみ測定 (TMA), 誘電緩和 測定 (DES) および動的粘弾性測定 (DMS) は，セイコーインスッ ルメンツ制製 EXSTAR 6000 (TMA 120，DES 100およびDMS 210 ) (測定条件 : 窒素気流下, 昇温速度 $2{ }^{\circ} \mathrm{C} / \mathrm{min}$ ) を用いて行っ た。

\section{3 主鎖に二置換アミド型 NBD 構造を有するポリ（エステル} /アミド) (P-1)の合成

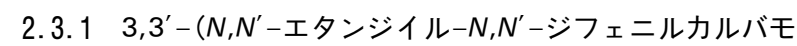
イル)ビス(ノルボルナジェン-2-カルボン酸) (EDPNC) とビスフ エノール A ジグリシジルエーテル (BPGE) との重付加反応 (P-1 の合成）：触媒としてテトラブチルアンモニウムブロミド (TBAB) $0.032 \mathrm{mg}(0.01 \mathrm{mmol})$ をアンプル管にはかり取り，60 ${ }^{\circ} \mathrm{C}$ で 5 時間減圧乾燥を行った. 乾燥後, EDPNC $1.07 \mathrm{~g}(2 \mathrm{mmol})$ と BPGE $0.685 \mathrm{~g}(2 \mathrm{mmol})$, 抢よび溶媒としてNMP $3 \mathrm{~mL}$ をア ンプル管に加え, 窒素を用いて 2 回凍結脱気を行い, 封管した 後に $100{ }^{\circ} \mathrm{C} て ゙ 12$ 時間反応させた. 反応終了後, 反応溶液をメ夕 ノールに注ぎポリマーを沈殿させた，得られたポリマーは，良溶 媒に THF，貧溶媒にメタノールを用い， 2 回再沈精製を行った
後, 室温で減圧乾燥した。

収率： $1.59 \mathrm{~g}(99 \%)$.

数平均分子量 $\left(M_{\mathrm{n}}\right): 42600$ 分子量分布 $\left(M_{\mathrm{w}} / M_{\mathrm{n}}\right): 1.61$

$\operatorname{IR}\left(\right.$ film, $\left.\mathrm{cm}^{-1}\right)$ : $3436\left(v_{\mathrm{O}-\mathrm{H}}\right), 1708\left(v_{\mathrm{C}=\mathrm{O}}\right.$, ester $), 1645\left(v_{\mathrm{C}=\mathrm{O}}\right.$, amide $)$, $1234\left(v_{\mathrm{C}-\mathrm{O}-\mathrm{C}}\right)$.

${ }^{1} \mathrm{H}-\mathrm{NMR}\left(200 \mathrm{MHz}, \mathrm{DMSO}-d_{6}\right.$, TMS), $\delta$ (ppm) : 1.05-1.90 (m, $10.0 \mathrm{H}, \mathrm{CH}_{2}$ in $\left.\mathrm{NBD}, \mathrm{CH}_{3}\right), 3.54-4.28(\mathrm{~m}, 17.8 \mathrm{H}, \mathrm{CH}$ in NBD, $\left.\mathrm{CH}, \mathrm{CH}_{2}\right), 5.00-5.33(\mathrm{~m}, 2.0 \mathrm{H}, \mathrm{OH}), 6.66-7.56(\mathrm{~m}, 21.9 \mathrm{H}, \mathrm{CH}$ $=\mathrm{CH}$ in NBD, aromatic $\mathrm{H})$.

\section{4 ポリマーの熱特性}

$\mathrm{P}-1$ の THF 溶液をガラス板に鋳达み, 室温で減圧乾燥させ た. 光源に $500 \mathrm{~W}$ の Xe ランプを用い(照度 : $1.42 \mathrm{~mW} / \mathrm{cm}^{2}(310$ $\mathrm{nm})$ ), ガラス板上のフィルムに 24 時間光照射を行い, $\mathrm{P}-1$ の $\mathrm{NBD}$ 構造を $\mathrm{QC}$ 構造に変換させた. 異性化したポリマーフィル ム $(3.00 \mathrm{mg})$ を DSC 測定用のアルミニウムパンに封入し, 窒素 雲囲気下, $10{ }^{\circ} \mathrm{C} / \mathrm{min}$ で $25-280^{\circ} \mathrm{C}$ まで昇温させ, 発熱ピークの 面積を積分して蓄熱量として算出した。ポリマーの熱重量減少温 度 (decomposition temperature) は，TG/DTA を用いて窒素雾囲 気下, $10{ }^{\circ} \mathrm{C} / \mathrm{min}$ の昇温速度で $25-550{ }^{\circ} \mathrm{C}$ をで測定し, 重量減少 が始まる接線の温度を $T_{\mathrm{d}}$ として求めた。

\section{5 ポリビニルアルコールをコーティングした場合の屋外暴} 露試験

2.5.1 フィルム作成: P-1 を THF に溶解させ, ポリエチレ ンシート上の $3 \mathrm{~cm} \times 3 \mathrm{~cm}$ に区切られた枠内に鋳込みし, 室温で 2 日間, 減圧乾燥した. フィルムの厚さはマイクロメーターを用 いて測定し，約 $30 \mu \mathrm{m}$ となるように調製した．このP-1フィル ムに水に溶解させたPVA をコーティングし, 室温で 3 日間減圧 乾燥させた．PVAの膜厚は約 $10,20,30 \mu \mathrm{m}$ になるように調製 した．このフィルムをポリエチレンシートで覆い, 地上 5 階の 屋上, 正南面, 試料の傾斜角度 $45^{\circ}$ に設置し, 1999 年 11 月 10 日から 2000 年 2 月 10 日の 3 か月間自然暴露試験を行った.

2.5 .2 蓄熱量の測定 : 太陽光にさらしたポリマーフィルム $(3.00 \mathrm{mg})$ を DSC (differential scanning calorimetry) 測定用のア ルミニウムパンに封入し，DSCを用いて窒素雾囲気下，25-280 ${ }^{\circ} \mathrm{C}$ な゙ $10{ }^{\circ} \mathrm{C} / \mathrm{min}$ で昇温させ, 発熱ピークの面積を積分して蓄熱 量として算出した.

2.5.3 $T_{\mathrm{g}}$ の測定：ガラス転移温度 $\left(T_{\mathrm{g}}\right)$ は, TMA (thermomechanical analysis) 測定 (針入法, 窒素雾囲気下, $2{ }^{\circ} \mathrm{C} / \mathrm{min}$ ) を用いて測定した．暴露したサンプル $(3 \mathrm{~mm} \times 3 \mathrm{~mm} \times 30 \mu \mathrm{m})$ に TMA の針入グローブを当てて荷重 $10 \mathrm{~g}$ を加え， 25-200 ${ }^{\circ} \mathrm{C}$ で温度を上昇させながら針が急激に動き出す温度を $T_{\mathrm{g}}$ として求 めた。

2.5.6 分子量の測定 : 暴露したサンプル約 $2 \mathrm{mg}$ を THF に浸 し, その可溶部の GPC 測定を行い, 数平均分子量 $\left(M_{\mathrm{n}}\right)$ を求めた。

\section{6 屋外暴露による分子運動性の検討}

2.6.1 誘電分散緩和測定 : 誘電分散緩和測定 (DES)により分 子運動性ついて検討を行った. サンプルは, 誘電測定用の電極板 に $\mathrm{P}-1$ の THF 溶液を鋳込みし, 室温で 24 時間乾燥後, 2 日間 減圧乾燥して直径 $45 \mathrm{~mm}$, 厚さ約 $30 \mu \mathrm{m}$ のフィルムを作成し, 他の試料と同時に屋外暴露した。液体窒素と乾燥窒素を用いて - $100{ }^{\circ} \mathrm{C}$ まで冷却した後, 昇温速度 $2{ }^{\circ} \mathrm{C} / \mathrm{min}$ で $120{ }^{\circ} \mathrm{C}$ まで昇温 させた. 測定は, 周波数 $1000 \mathrm{~Hz}$ で行った. 
2.6.2 動的粘弾性測定 : 動的粘弾性測定 (DMS)により分子運 動性ついて検討を行った. サンプルは, 暴露した $\mathrm{P}-1$ フィルム から $3 \mathrm{~cm} \times 0.5 \mathrm{~cm} \times 30 \mu \mathrm{m}$ の長方形をカッターで切り出したも のを用いた．液体窒素と乾燥窒素を用いて $-100{ }^{\circ} \mathrm{C}$ を泠却した 後, 昇温速度 $2{ }^{\circ} \mathrm{C} / \mathrm{min}$ で $150{ }^{\circ} \mathrm{C}$ をで昇温させた。測定は, 周波 数 $1 \mathrm{~Hz}$ で行った.

\section{7 光安定剂を添加した場合の耐候性}

P-1 を THF に溶解させ, 光安定剤として UV1084 (0.05 mol. amt.) 抢よび UV3346 (0.05 mol.amt.)を添加し, 室温で均一混合 させた。この溶液をポリエチレンシート上に鋳込みし, 室温で減 圧乾燥させた．フィルムの厚さはマイクロメーターを用いて測定 し，約 $30 \mu \mathrm{m}$ となるように調製した．このフィルムをポリエチ レンシートで覆い，2.5 と同様に屋外暴露試験を行った．光安定 剂を添加した P-1 フィルムの暴露試験は，1999 年 11 月 10 日か ら 2000 年 2 月 10 日の 3 か月間行った.

\section{8 ガラス板でフィルムを保護した場合}

約 $30 \mu \mathrm{m}$ に作成した $\mathrm{P}-1$ フィルムをガラス板 $(30 \mu \mathrm{m})$ で保護 し,このフィルムをポリエチレンシートで覆い, 同様に自然暴露 試験を行った．P-1フィルムのガラス板による保護の検討におけ る暴露試験は, 1999 年 11 月 10 日から 2000 年 2 月 10 日の 3 か 月間行った.

\section{3 結果と考察}

$3.13,3^{\prime}-\left(N, N^{\prime}-\right.$ エタンジイル-N,N'-ジフェニルカルバモイ ル)ビス(ノルボルナジェン-2-カルボン酸) (EDPNC) とビスフェ ノールA ジグリシジルエーテル (BPGE) との重付加反応による $\mathrm{P}-1$ の合成

主鎖に二置換アミド型 NBD 構造を有するポリ（エステル/アミ ド）(P-1)は，既報7)に従い，EDPNCとBPGEを触媒として, TBAB を用い, NMP 中, $100{ }^{\circ} \mathrm{C} て ゙ 12$ 時間反応させることによ り合成した (Scheme 1). その結果 (Table 1), 数平均分子量 48000 のポリマーが収率 $99 \%$ で得られた。構造は, IR および ${ }^{1} \mathrm{H}-\mathrm{NMR}$ により確認した.

\section{2 ポリマーの熱特性}

DSC を用いて, 得られたポリマーのガラス転移温度 $\left(T_{\mathrm{g}}\right)$ を測 定した。 また, TG/DTA を用いて, 熱重量減少温度を測定し,

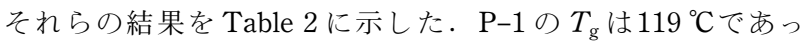
た。 また， NBD から QC に異性化したポリマーは， $T_{\mathrm{g}}$ 以上の温 度で徐々に NBD に逆異性化することが知られていることから，
Table 1 Preparation of the poly (ester/amide)

\begin{tabular}{cccc}
\hline Polymer & Yield $/ \%$ & $\left.10^{-4} M_{\mathrm{n}} \mathrm{a}\right)$ & $M_{\mathrm{w}} / M_{\mathrm{n}}$ a) \\
\hline $\mathrm{P}-1$ & 99 & 4.3 & 1.61 \\
\hline
\end{tabular}

a) Estimated by GPC based on polystyrene standards in THF.

Table 2 Thermal properties of the poly (ester/amide)

\begin{tabular}{ccccc}
\hline \multirow{2}{*}{ Polymer } & $T_{\mathrm{g}} /{ }^{\circ} \mathrm{C}^{\mathrm{a})}$ & $\mathrm{DT}_{5} /{ }^{\circ} \mathrm{C}^{\mathrm{b})}$ & \multicolumn{2}{c}{ Stored thermal energy ${ }^{\mathrm{c}}$} \\
\cline { 4 - 5 } & & & $\mathrm{kJ} \mathrm{mol}^{-1}$ & $\mathrm{~J} \mathrm{~g}^{-1}$ \\
\hline $\mathrm{P}-1$ & 119 & 348 & 95 & 228 \\
\hline
\end{tabular}

a) Glass transition temperature determined by DSC heating rate 10 ${ }^{\circ} \mathrm{C} / \mathrm{min}$.

b) Five $\%$ weight-loss temperature observed by TG heating rate $10^{\circ} \mathrm{C} / \mathrm{min}$.

c) Measured by DSC heating rate $10^{\circ} \mathrm{C} / \mathrm{min}$.

$T_{\mathrm{g}}$ が 119であることは, 室温付近で QC から NBD への逆異性化 が起こらず，保存安定性に優れたポリマーであることを示唆して

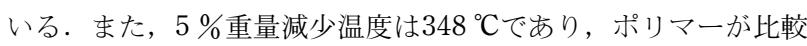
的高い熱安定性を示すことも判明した。これは，ポリマー骨格中 に熱的に安定なビスフェノール A 構造とアミド結合を有するた めと思われる.

十分に光照射を行った後の QC 残基を有するポリマーの蓄熱量 はDSCを用いて測定し，発熱量を蓄熱量として算出した。その 結果, P-1の蓄熱量は, $95 \mathrm{~kJ} / \mathrm{mol}$ であった。 また, NBD ポリ マーを実用的に利用することを考えると，単位重量当たりの蓄熱 量で評価する必要があり，P-1の蓄熱量を単位重量当たりに換算 すると $228 \mathrm{~J} / \mathrm{g}$ と比較的高い蓄熱量を有することがわかった.

\section{3 屋外暴露試験}

3.3.1 蓄熱量の変化 : 得られた $\mathrm{P}-1$ の耐候性を調べるために 約 $30 \mu \mathrm{m}$ のフィルムを作成した。 また, 酸素透過性が低く, P-1 と溶解性が異なるPVA をコーティング材として選択し，約 10 $\mu \mathrm{m}$ の PVA をコーティングした試料を作成した．屋外暴露試験 に拈いて，気象因子として太陽光のほかに，風や雨などがある が，季節により風量，雨量や $\mathrm{pH}$ 濃度が異なる．そのため耐候性 を調べるためには，これらから守るために試料をポリエチレン シートで覆った。このPVA とポリエチレンシートは, NBD 構 造の吸収波長域に大きな吸収を持たないため, NBD 構造の光異 性化を妨げないため NBD ポリマーの保護として有用であると考

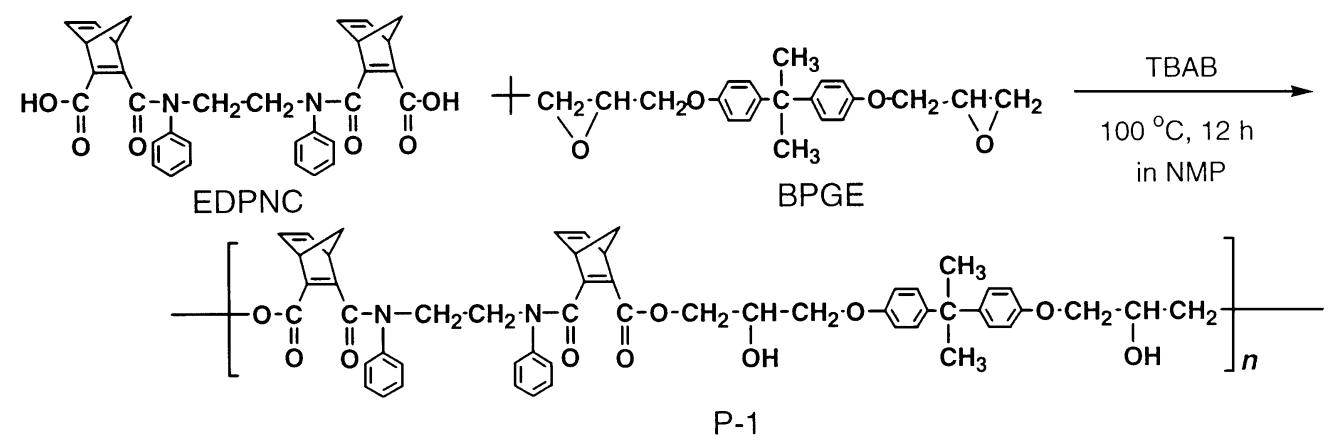

Scheme 1 


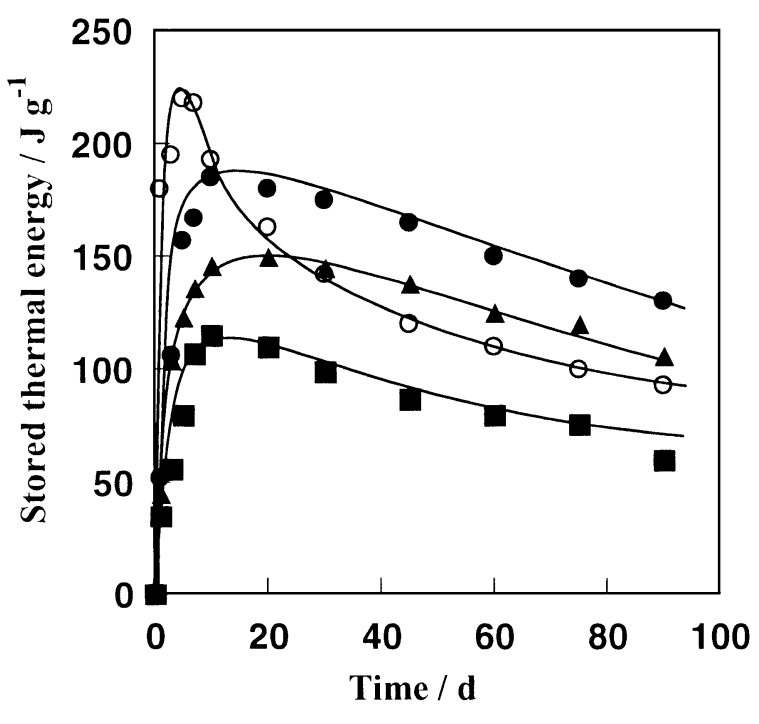

Fig. 1 Change of stored thermal energy of $\mathrm{P}-1$ coated with PVA film on the outdoor exposure; $(\bigcirc)$ none, PVA $10 \mu \mathrm{m}$, (ム) PVA $20 \mu \mathrm{m}$, (ם) PVA $30 \mu \mathrm{m}$.

えられる. 暴露期間の経過に伴う, 蓄熱量の变化を Fig. 1 に示 した. その結果, PVAをコーティングしていない P-1フィルム の蓄熱量は暴露 5 日目 $(228 \mathrm{~J} / \mathrm{g})$ まで上昇し, その後暴露期間の 経過に伴い, 徐々に減少する傾向が認められた.このことから, 太陽光により光原子価異性化し, 生成した $\mathrm{QC}$ 構造あるいは NBD 構造の化学変化や分子鎖間での架橋反応が起こったと考え られる. 一方, PVAをコーティングしたフィルムでは, PVAを 含む試料で測定しているため, 蓄熱量を単位重量当たりに換算す ると低い值であるが，蓄熱量の減少はコーティングなしと比較し て，抑えられることが判明した，また，見かけ上の蓄熱量は低い 值であったが, PVAの膜厚が厚いほどその減少が抑えられるこ とが判明した。

3.3.2 $T_{\mathrm{g}}$ の変化: 暴露した $\mathrm{P}-1$ フィルムの $T_{\mathrm{g}}$ は, $\mathrm{QC}$ 構造 から NBD 構造への熱による逆異性化に伴う発熱ピークの開始温 度 $\left(100{ }^{\circ} \mathrm{C}\right)$ 付近にあり, DSC 測定により $T_{\mathrm{g}}$ を求めることが困難 であった．そこで，TMA 測定の針入法により $T_{\mathrm{g}}$ を求めた．暴 露期間の経過に伴う $\mathrm{P}-1$ フィルムおよび $\mathrm{P}-1$ フィルムに PVA をコーティングしたフィルムの $T_{\mathrm{g}}$ の変化を Fig. 2 に示した. 暴 露期間の経過に伴い，暴露 10 日までに $T_{\mathrm{g}}$ が徐々に上昇し，そ の後暴露 30 日までに $T_{\mathrm{g}}$ が急激に上昇する傾向が見られた．ま た, 暴露 30 日以降では, $T_{\mathrm{g}}$ が徐々に上昇した。これは, 暴露初 期に抢いてポリマーの分子間で架橋反応が徐々に進行し, フィル ム中に三次元網目構造が形成され, その後, 架橋密度が増大した ためであると考えられる. 暴露 30 日以降, 架橋反応は, 徐々に 進行したと考えられる. 一方，P-1フィルムに PVA をコーティ ングしたフィルムでは, 暴露初期における $T_{\mathrm{g}}$ の上昇が抑えられ る傾向がみられた。 また, その効果はPVAの膜厚に依存し, 膜 厚30 $\mu \mathrm{m}$ の場合, 酸素の影響が小さく, 架橋反応を抑制したと思 われる.

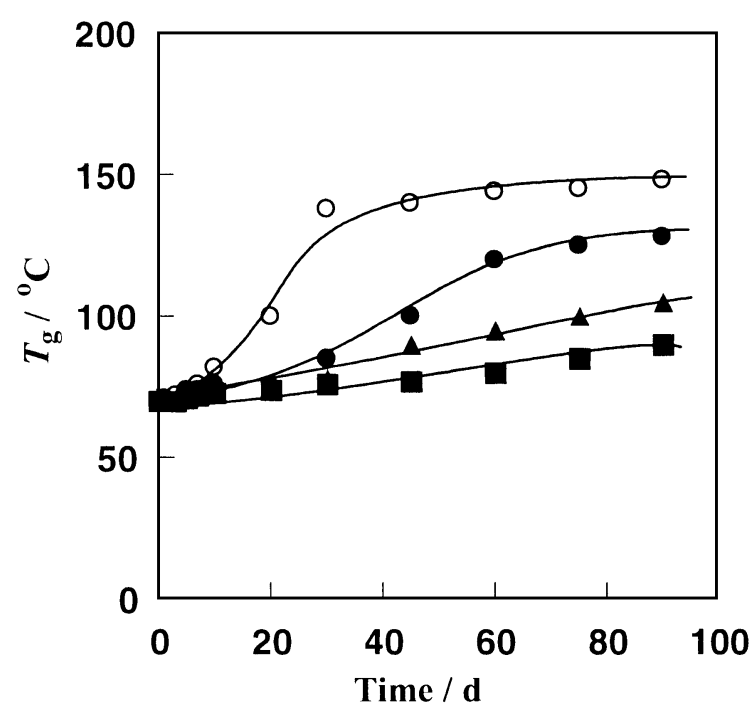

Fig. 2 Change of $T_{\mathrm{g}}$ of $\mathrm{P}-1$ coated with PVA film on the outdoor exposure ; $\bigcirc$ ) none, (O) PVA $10 \mu \mathrm{m}$, PVA $20 \mu \mathrm{m}$, (ם) PVA $30 \mu \mathrm{m}$.

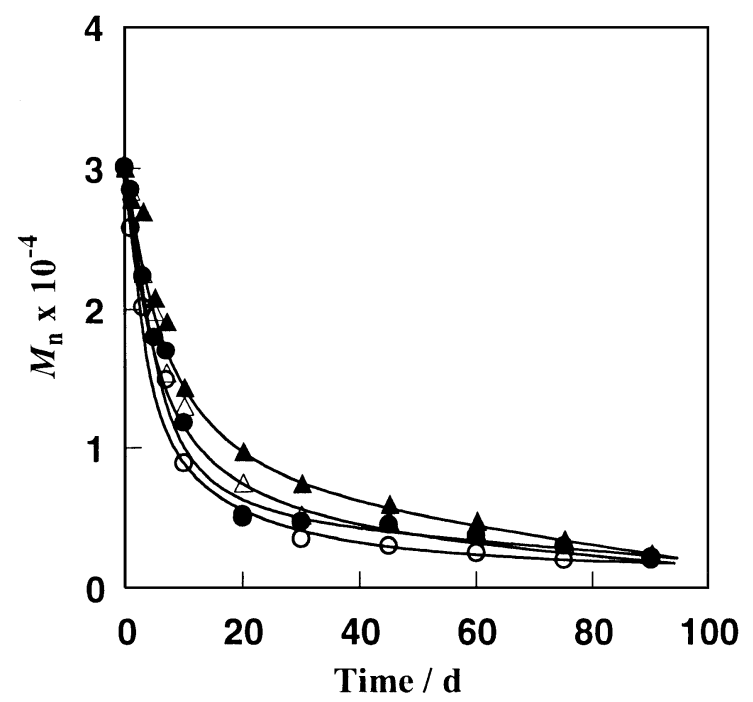

Fig. 3 Change of molecular weight $\left(M_{\mathrm{n}}\right)$ of $\mathrm{P}-1$ coated with PVA film on the outdoor exposure of soluble parts in THF ; ( $\bigcirc)$ none, $(\bigcirc)$ PVA $10 \mu \mathrm{m},(\mathbf{\Delta})$ PVA $20 \mu \mathrm{m}$,

(ם) PVA $30 \mu \mathrm{m}$.

3.3.3 フィルム可溶部の分子量の変化 : 暴露した $\mathrm{P}-1$ フィル 厶可溶部の分子量の変化を Fig. 3 に示した. 分子量は, 暴露 10 日間で急激に減少する傾向が見られた. フィルム内の光劣化を防 止するために， 10, 20,30 $\mu \mathrm{m}$ の膜厚のPVA をそれぞれ表面に コーティングしたが，PVAの膜厚に関係なく表面保護の効果は 見られなかった．このことから，フィルム表面をコーティング材 によって保護した場合でもポリマーの主鎖切断が起ったと考えら れる.この原因として，P-1フィルム内部の酸素による自己酸化 反応や加水分解が起ったことが考えられる. 


\section{4 構造変化}

3.4.1 IR による構造変化の解析 : 一般に, ポリマーの太陽光 による光劣化において, 高分子のさまざまな部分での切断が考光 られる， P-1の場合では，アミド結合の $\mathrm{C}(\mathrm{O})-\mathrm{N}$ 間が切れやす く, $-\mathrm{NH}-\mathrm{CH}_{2}-$ - $-\mathrm{CH}_{2}-$ の位置が自動酸化を受けやすいことが考 えられる。 また，エステル結合の $\mathrm{C}(\mathrm{O})-\mathrm{O}-\mathrm{C}$ 間が加水分解を受 けやすいことが知られている ${ }^{9)}$ そこで, 暴露したフィルムの光 劣化に打ける構造変化について検討を行った，始めに，暴露した フィルムを $\mathrm{KBr}$ (錠剤) 法を用いて IR 測定を行ったが， IR スペ クトルの吸収を得ることができなかった．これは，暴露したフィ ルムが架橋しているために硬く, フィルムの粉砕が困難であった ため $\mathrm{KBr}$ と混合しなかったことが原因と考えられる．次に，暴 露したフィルムの状態で直接 IR 測定を行った。 その結果, IR スペクトルでは, 全体的にブロードな吸収が見られ, 構造を確認 することができなかった．これは，暴露したフィルムが $30 \mu \mathrm{m}$ と厚いため赤外光の透過性が低いためであると考えられる. そこ で， $10 \mu \mathrm{m}$ のフィルムを作成し，このフィルムに $500 \mathrm{~W}$ の Xe ラ ンプで光照射を行い，光照射過程における構造変化について調べ た (Fig. 4). その結果， 24 時間の光照射により $1620 \mathrm{~cm}^{-1}$ の $\mathrm{NBD}$ 構造に起因する $\mathrm{C}=\mathrm{C}$ の吸収の消失が確認された。これは, $\mathrm{P}-1$ の NBD 構造が定量的に QC 構造に異性化したことを示唆し ている。 また， $1232 \mathrm{~cm}^{-1}$ のエステルに起因する $\mathrm{C}(\mathrm{O})-\mathrm{O}-\mathrm{C}$ の

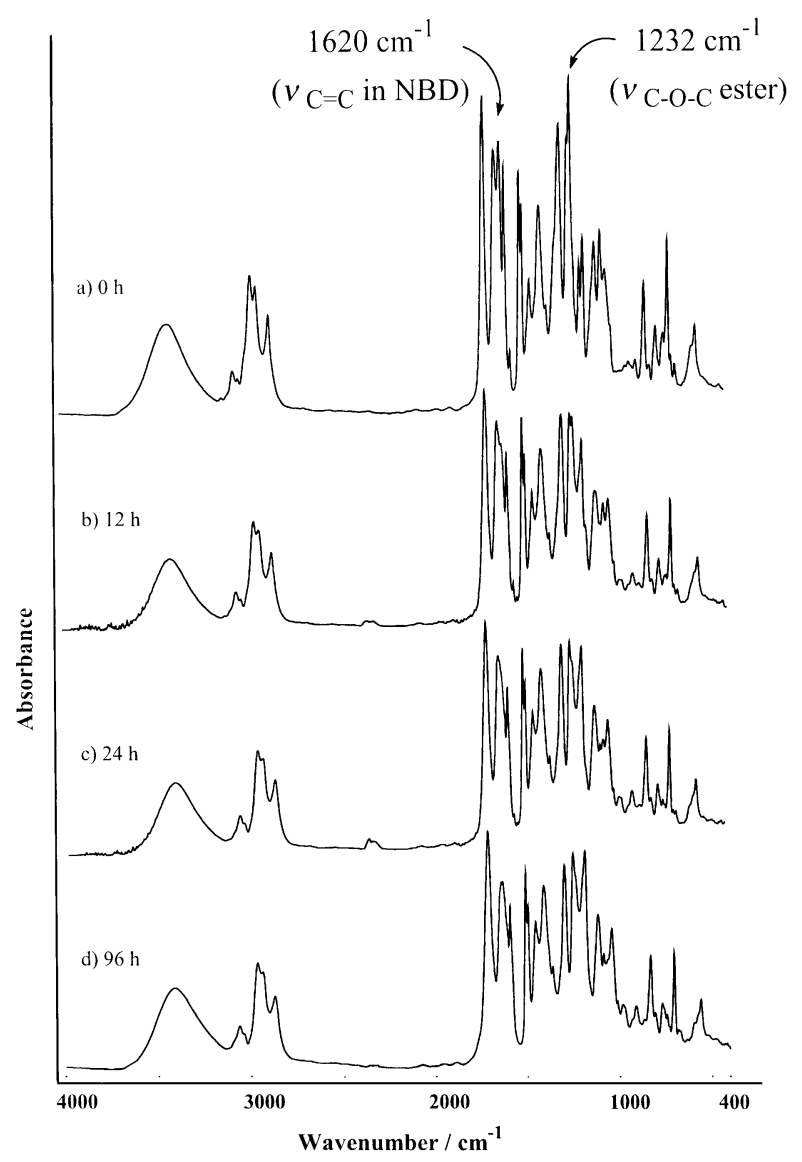

Fig. 4 Change of IR spectra of $\mathrm{P}-1$ film upon irradiation with Xe lamp $\left(1.30 \mathrm{~mW} / \mathrm{cm}^{2}\right.$ at $\left.310 \mathrm{~nm}\right)$.
吸収が徐々に減少した。これは，エステルに起因する C $(\mathrm{O})$ -O-Cが光照射に伴い，切断されたと考えられる．しかしなが ら，その切断により新たに生じると考えられる- $\mathrm{OH}$ 基， $\mathrm{OOH}$ 基， $\mathrm{CH}$ 基, $\mathrm{CH}_{2}$ 基, $\mathrm{CH}_{3}$ 基などの吸収は確認されなかった。 また, 光の照射時間の経過に伴い，全体的な吸収強度は低下した。これ は，光照射によりフィルムが架橋したことを示唆している．以上 の結果から，P-1 は，光照射によりエステルに起因する $\mathrm{C}(\mathrm{O})$ -O-C の切断や架橋反応を生じたことが確認された.

3.4.2 ${ }^{1} \mathrm{H}-\mathrm{NMR}$ による構造変化の解析 : 次に, 暴露したフィ ルムを DMSO- $d_{6}$ に溶解させ，その可溶部の ${ }^{1} \mathrm{H}-\mathrm{NMR}$ 測定を行 った．暴露期間の経過に伴う， ${ }^{1} \mathrm{H}-\mathrm{NMR}$ スペクトル変化を Fig. 5 に示した．その結果，暴露 10 日目で $1.85-2.35 \mathrm{ppm}$ に帰属が 難しい新たなシグナルが観察された．これは，光劣化により主鎖 切断が起こり，新たな官能基が生じたことを示唆している. また， NBD に起因するすべてのシグナルが減少した.これは, 太陽光 暴露により $\mathrm{NBD}$ から $\mathrm{QC}$ 構造への光原子価異性化抢よび $\mathrm{NBD}$ 構造の副反応による架橋のためであると思われる。しかしなが ら，それらの ${ }^{1} \mathrm{H}-\mathrm{NMR} に$ に扔いて基準となるシグナルを決定でき ないため，それぞれのシグナルの積分強度比から主鎖の切断や架 橋の割合を求めることは困難であった。

\section{5 分子運動解析}

3.5.1 誘電緩和測定による分子運動性の変化 : 誘電緩和測定 を行い，暴露過程における分子運動性について調べ，暴露に伴う ポリマーの構造変化について検討を行った. 暴露した $\mathrm{P}-1$ フィ ルムの $\tan \delta$ の温度依存性を Fig. 6 に示した。暴露初期では, $80{ }^{\circ} \mathrm{C}$ 付近にポリマーの局所的分子運動に起因するピーク $(\beta$ 分 散)が観察された。 また， $30{ }^{\circ} \mathrm{C}$ 付近から $T_{\mathrm{g}}$ によるポリマーのミ クロブラウン運動に起因する $\alpha$ 分散が観察された。また，暴露 1 日目の $\alpha$ 分散の温度は高温側にシフトし, $\tan \delta$ の值は上昇し た.これは, 昇温速度 $2{ }^{\circ} \mathrm{C} / \mathrm{min}$ で $\alpha$ 分散の温度領域に打いて, 異性化した $\mathrm{QC}$ 構造から $\mathrm{NBD}$ 構造への熱による逆異性化反応が 進行し，その発熱によりポリマーの分子運動性が高められたため に $\tan \delta$ が大きな值を示したと思われる．その後屋外暴露期間の 経過に伴い, 全体的に $\tan \delta$ の值は徐々に減少し， $\alpha$ 分散は高温 側にシフトすることが確認された。この $\alpha$ 分散のシフトは，新た に三次元架橋構造が生成し，ポリマーのミクロブラウン運動が抑 制されたため, 高温側に $\alpha$ 分散が移動したものと考えられる. これらのことから，屋外暴露によってポリマーの局部だけでな く，分子鎖全体の運動性が低下したためであると考えられ，主鎖 の切断や架橋ポリマーの生成が起きたことが示唆された.

3.5.2 動的粘弾性測定による分子運動性の変化：動的粘弾性 測定を行い，暴露過程に扔ける分子運動性について調べ，暴露に 伴うポリマーの構造変化の検討を行った．暴露した $\mathrm{P}-1$ フィル ムの弾性率 $\left(\varepsilon^{\prime}\right)$ の温度依存性を Fig. 7 に示した. 未暴露フィルム のガラス領域の弾性率は, $108 \mathrm{~Pa}$ 程度の值を示し, 強度の高い ポリマーであることが判明した。これは，ポリマーの主鎖骨格中 にアミド結合やビスフェノール A の硬い構造を有することから 機械的性質に優れていると考えられる. 暴露期間の経過に伴い, 弾性率は暴露 30 日目まで増加し, その後低下した。これは, 暴 露初期で分子間架橋のために弾性率が増加したが，さらに暴露期 間が増すとポリマー主鎖の分解に伴い，フィルム強度が低下寸る ために弾性率が減少したと思われる. 


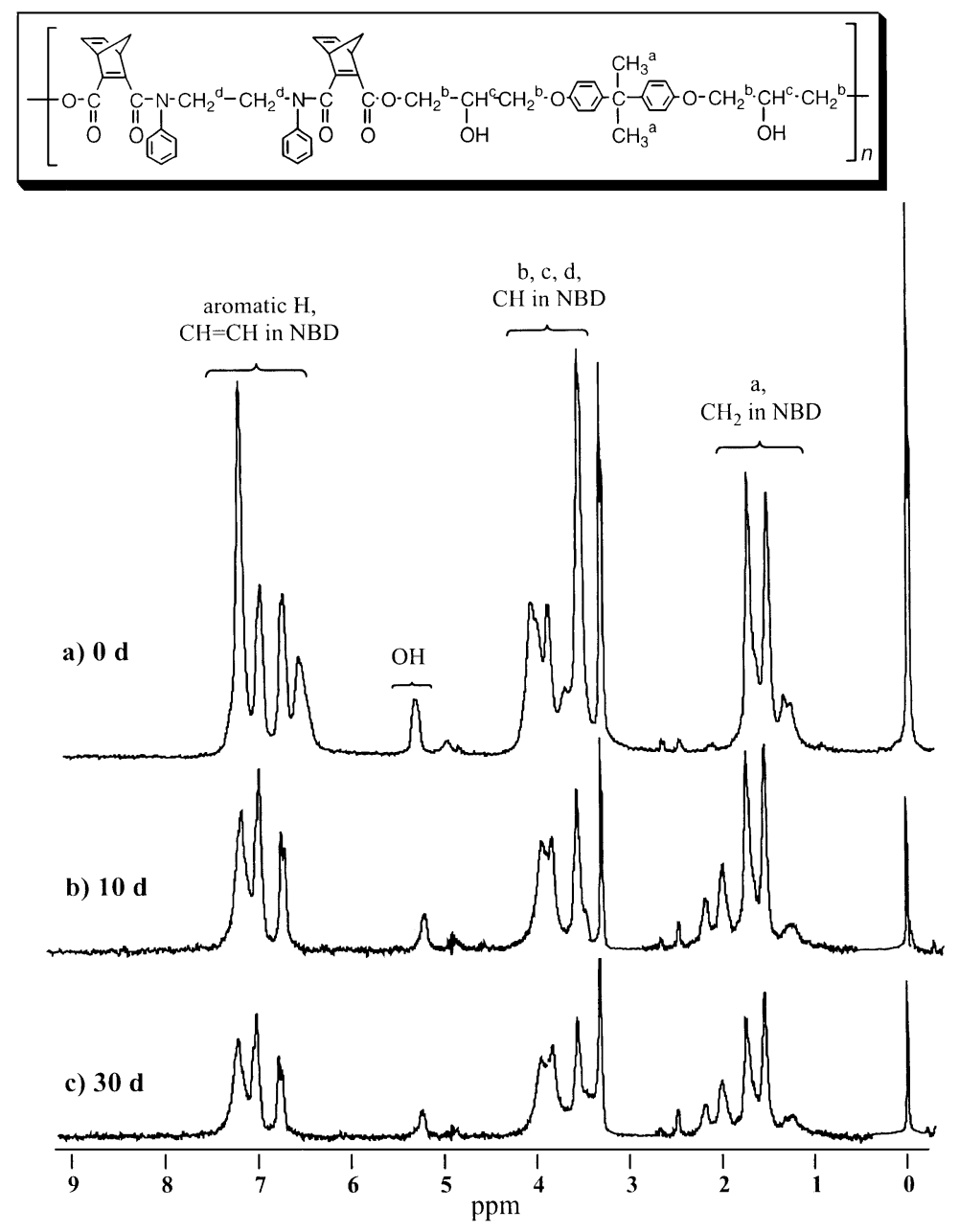

Fig. 5 Change of ${ }^{1} \mathrm{H}-\mathrm{NMR}$ on the outdoor exposure of $\mathrm{P}-1$ film.

a) This film was not exposed. b) This film was exposed under sunlight for 10 days. c) This film was exposed under sunlight for 30 days.

\section{$3.6 \mathrm{P}-1$ フィルムの耐候性の向上}

3.6.1 光安定剤の添加効果 : 光酸化反応により発生したラシ カルを捕捉することを目的として, 光安定剤を添加した P-1 ィルム $(30 \mu \mathrm{m})$ について同様の条件下で耐候性の検討を行った. 光安定剂を添加した $\mathrm{P}-1$ フィルム $(30 \mu \mathrm{m})$ の暴露期間の経過に伴 う蓄熱量と $T_{\mathrm{g}}$ の変化を Fig. 8 に示した. 光安定剤を添加しない 場合， P-1の蓄熱量の最大值は， $230 \mathrm{~J} / \mathrm{g}$ を示した。光安定郕 (UV1084, UV3346)を添加した場合の蓄熱量は，141 J/g, $183 \mathrm{~J} /$ gであった。これは，それぞれ無添加の場合の蓄熱量の 6 割，8 割に相当した．UV1084やUV3346を添加することにより光異性 化が若干低下する傾向が認められた。蓄熱量から考えると光安定 郕としては，UV3346が適していると考えられる．また，光安定 鼡を添加してない場合，P-1の10日目以降の蓄熱量は, 急激に 減少したのに対して，光安定剤を添加した場合，照射期間 20 日 目以降の蓄熱量の減少がごくわずかであった。このことから，光 安定剤を添加することにより蓄熱量の減少を抑制し，耐候性が向 上することがわかった．

$T_{\mathrm{g}}$ について比較すると, 光安定剤を用いた場合, 光安定剂を
添加しない場合と比較して，上昇が抑制される傾向が見られた。 また，UV1084と UV3346のそれぞれの効果の違いはほとんぞ認 められなかった：このことから，P-1に光安定剂を添加すること は，P-1 に対する光照射量を低下させ，さらに架橋の原因として 考えられる活性酸素ラジカルの影響を低下させたと考えられる. 以上の結果から，P-1にUV3346を光安定剂として添加すること は，P-1の耐候性を向上させるのに有効であると考えられる.

3.6.2 ガラス板による保護効果 : ガラス板でカバーした P-1 フィルム $(30 \mu \mathrm{m})$ についても同様に耐候性の检討を行った. ガラ ス板でカバーした $\mathrm{P}-1$ フィルム $(30 \mu \mathrm{m})$ の暴露期間の経過に伴う 蓄熱量と $T_{\mathrm{g}}$ の変化を Fig. 9 に示した。 その結果, 照射期間 60 日後の蓄熱量は, 理論値 $(230 \mathrm{~J} / \mathrm{g})$ とほほ同じ值 $(228 \mathrm{~J} / \mathrm{g})$ を示し た.これは，ガラス板で保護することにより，P-1フィルムに照 射される光量が相対的に減少し, そのため保護しない場合と比較 して, ゆっくりと光原子価異性化が進行したためと考えられる. また，Fig. 9 において， $T_{\mathrm{g}}$ の変化について見るとガラス板で保 護した場合， $T_{\mathrm{g}}$ の上昇が無保護に比較して抑制される傾向が見 られた．これは，ガラス板で保護することにより，紫外領域の光 


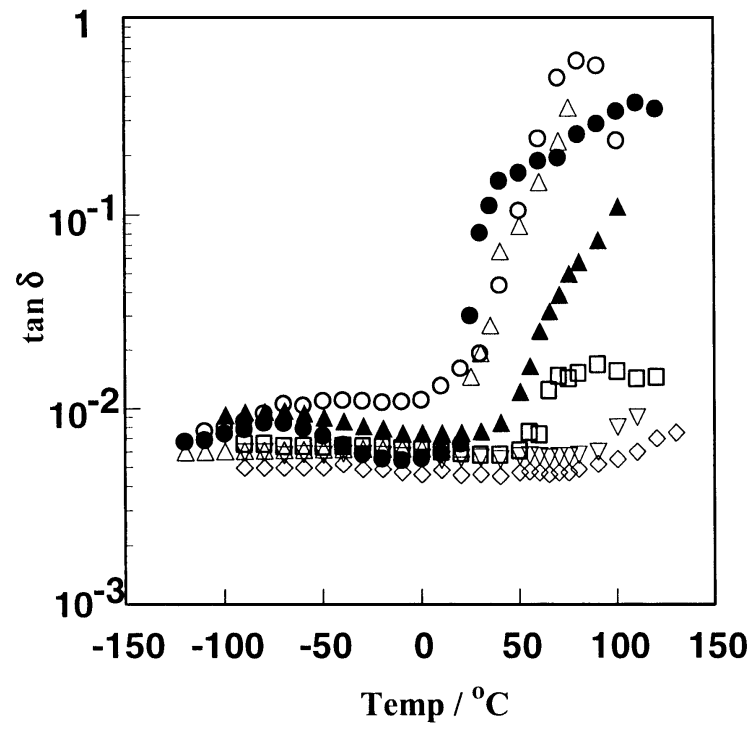

Fig. 6 Dielectric $\tan \delta$ of $\mathrm{P}-1$ on the outdoor exposure determined by DES; $(\bigcirc) 0 \mathrm{~d},(\bigcirc) 1 \mathrm{~d},(\triangle) 3 \mathrm{~d},(\mathbf{\Delta}) 7 \mathrm{~d}$, ( $\square) 10 \mathrm{~d},(\nabla) 30 \mathrm{~d},(\diamond) 90 \mathrm{~d}$.

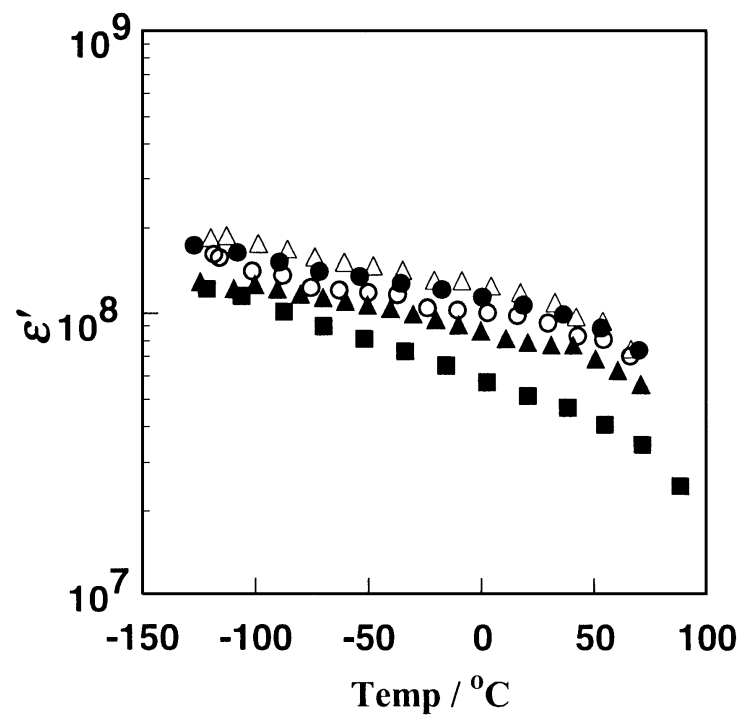

Fig. 7 Dynamic mechanical properties $\left(\varepsilon^{\prime}\right)$ of $\mathrm{P}-1$ on outdoor exposure determined by DES; $(\bigcirc) 0 \mathrm{~d},(\mathbf{O}) 10 \mathrm{~d}$,

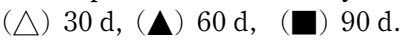

による架橋等が抑制されたことを意味している.ガラス板で NBD ポリマーの表面を保護することは，太陽光の紫外領域の光 の透過を減少させるが，空気中の酸素との接触を防ぎ，NBD や $\mathrm{QC}$ 構造の酸化反応や光劣化反応が抑制されるために，耐候性が 向上するものと考えられる.

\section{4 結 論}

1） P-1フィルムは, 暴露期間の経過に伴い蓄熱量の減少, $T_{\mathrm{g}}$ の上昇, 分解開始温度の減少など太陽光による劣化が見られ

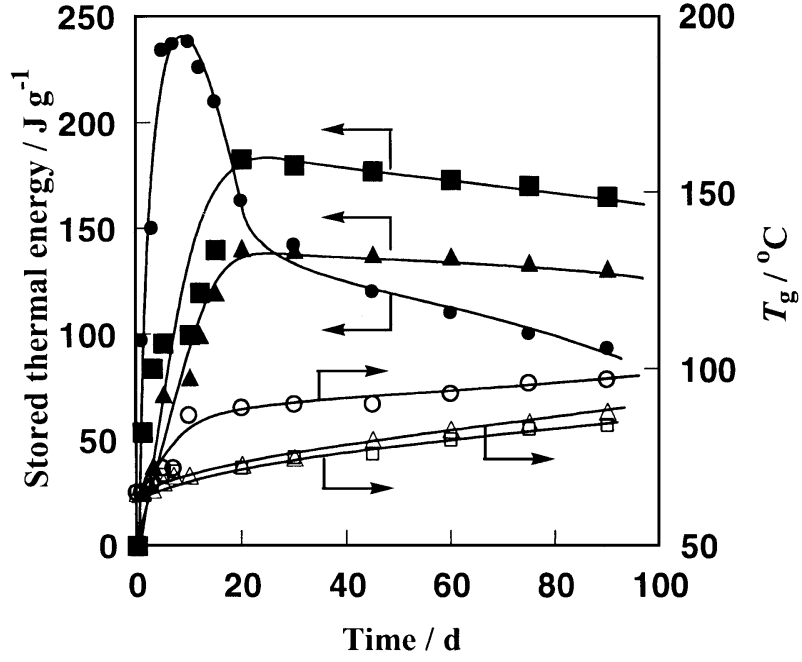

Fig. 8 Change of stored thermal energy and $T_{\mathrm{g}}$ on the outdoor exposure of $\mathrm{P}-1$ including light stabilizers $(0.05$ mol. amt.) films $(10 \mu \mathrm{m})$; (O) none, (A) UV1084, (ם) UV3346, ( $\bigcirc)$ none, $(\triangle)$ UV1084, $(\square)$ UV3346.
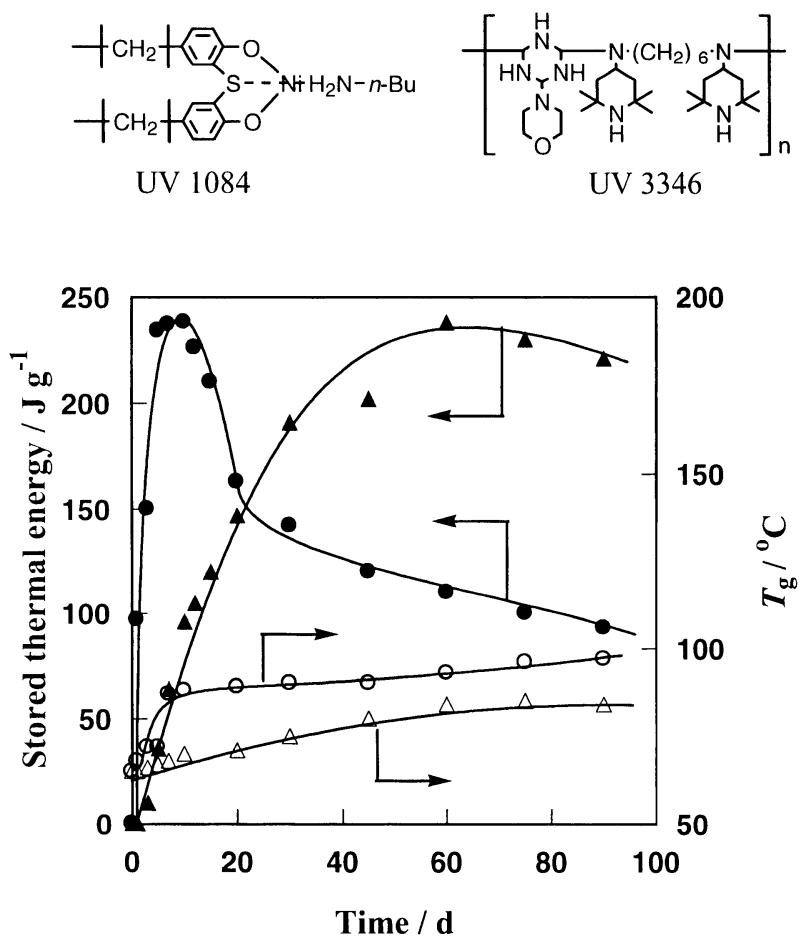

Fig. 9 Change of stored thermal energy and $T_{\mathrm{g}}$ of $\mathrm{P}-1$ coated with glass on the outdoor exposure; $(\mathbf{O})$ none, glass, $(\bigcirc)$ none, $(\triangle)$ glass.

たすすなわち，ポリマー間での架橋やポリマー主鎖の切断などが 起こっていることが明らかになった.

2） PVA やガラス板を用いてフィルム表面を保護することに より, 蓄熱量の減少や $T_{\mathrm{g}}$ の上昇を抑制することが可能であり, 耐候性を向上させることが判明した.

3）光安定剂を添加することにより，暴露期間の経過に伴い 
蓄熱量の減少， $T_{\mathrm{g}}$ の上昇を抑制し，耐候性を向上させることが 判明した.

1）日本化学会編, 化学総説 “エネルギー変換および新しい 燃料の化学”, No. 12, (1976), p. 30.

2）高分子錯体研究会編, “光エネルギー変換”, 学会出版セ ンター, (1983), pp. 245-280.

3) a) R. R. Hautala, J. Little, E. Sweet, Solar Energy, 19, 503, (1977); b) R. B. King, E. M. Sweet, J. Org. Chem., 44, 385, (1979); c) R. R. Hautala, R. B. King, C. Kutal, "Solar Energy; Chemical Conversion and Storage", Hamana Clifton, New Jersey(1979), p. 333.

4) 高村 聡, 亀山 敦, 西久保忠臣, 高分子論文集, 52, 415(1995).

5）津幡晃徳，亀山 敦，西久保忠臣，高分子論文集， 53， 530 (1996).

6) For example: a) T. Nishikubo, T. Shimokawa, A. Sahara,
Macromolecules, 22, 8(1989); b) T. Nishikubo, A. Kameyama, S. Watanabe, J. Polymer. Sci., Part A; Polym. Chem., 31, 1659 (1993); c) T. Tsubata, T. Uchiyama, A. Kameyama, T. Nishikubo, Macromolecules, 30, 5649 (1997); d) T. Nishikubo, A. Kameyama, K. Kishi, T. Kawashima, T. Fujiwara, C. Hijikata, Macromolecules, 25, 4469 (1992).

7) A. Ikeda, A. Tsubata, A. Kameyama, T. Nishikubo, J. Polym. Sci. Part A; Polym. Chem., 37, 917 (1999).

8) A. Tanaka, T. Nakai, E. Miyagawa, A. Nitta, H. Nakaya, Polymer Preprints, Jpn, 48, 919 (1999).

9) Y. Matsumura, S. Nakamura, Polymer Preprints, Japan, 43 , IP1b14(1994).

10) Y. J. Yu, F. W. Shen, H. A. Mckellop, R. Salvey, J. Polym., Sci. part A: Polym. Chem., 37, 3309(1999).

11）長部友加里, 亀山 敦, 中村茂夫, 西久保忠臣, 高分子 論文集，57, $300(2000)$.

\title{
Properties and Weatherability of Poly (ester/amide) Containing Norbornadiene Moieties in the Main Chain
}

\author{
Yukari Osabe, Atsushi Kameyama, Shigeo Nakamura and Tadatomi Nishikubo* \\ Department of Applied Chemistry, Faculty of Engineering, Kanagawa University; \\ 3-27-1 Rokkakubashi, Kanagawa-ku, Yokohama-shi 221-8686 Japan
}

In this paper, we report properties and weatherability of the poly(ester/amide) containing norbornadiene moieties in the main chain $(\mathrm{P}-1)$.

The thermal properties of $\mathrm{P}-1$ were investigated by TGA and DSC analyses. The $T_{\mathrm{g}}$ of $\mathrm{P}-1$ stood at $119{ }^{\circ} \mathrm{C}$, and a $5 \%$ weight loss was recorded at $348{ }^{\circ} \mathrm{C}$. The photoirradiated $\mathrm{P}-1$ film containing quadricyclane $(\mathrm{QC})$ groups released about $228 \mathrm{~J} / \mathrm{g}$ of thermal energy.

Weatherability of $\mathrm{P}-1$ was evaluated during on the outdoor exposure test in Yokohama for 3 months. The stored thermal energy of the $\mathrm{QC}$ groups in $\mathrm{P}-1$ gradually decreased as the outdoor exposure proceeded. These results are attributed to the cross-linking formation and the main chain rupture of $\mathrm{P}-1$ during the outdoor exposure.

The top-coating with PVA film and cover with glass plate on $\mathrm{P}-1$ was proved to be very effective to improve the weatherability of $\mathrm{P}-1$ film. It was also found that light stabilizers enhanced the weatherability of $\mathrm{P}-1$ film. 